WALDEMAR W. ŻUREK SDB* - LUBLIN

\title{
PARAFIA RZYMSKOKATOLICKA W MIKASZEWICZACH W DIECEZJI PIŃSKIEJ W ŚWIETLE INWENTARZA KOŚCIOLA Z 1938 ROKU
}

Osiemnastowieczna magnacka wieś Mikaszewicze na Kresach Wschodnich położona była w księstwie słuckim, powiecie i województwie nowogródzkim, nad niziną rzeki Wołchwy ${ }^{1}$. W okresie międzywojennym miasto było w granicach II Rzeczypospolitej, jak i pozostała zachodnia część Białorusi. W czasie drugiej wojny światowej okupowane przez Sowietów, a po wojnie znalazło się w granicach Związku Radzieckiego - w Białoruskiej Socjalistycznej Republice Radzieckiej. Obecnie Mikaszewicze (błędnie Mikaszewice, białoruskie Мікашэвічы) to miasto w południowej Białorusi, nad Wołchawą, w rejonie (powiecie) łuninieckim, w obwodzie (województwie) brzeskim, na Polesiu Prypeckim, na wschód od Pińska.

Architektoniczą osobliwością Mikaszewicz jest cerkiew Narodzenia Jana Chrzciciela, zbudowana w 1936 roku jako świątynia katolicka. W czasach komunizmu świątynia została zamknięta. Na początku lat dziewięćdziesiątych ubiegłego wieku została przekazana prawosławnym, którzy obiekt sakralny przebudowali na cerkiew.

$$
* * *
$$

Inwentarz parafialnego rzymsko-katolickiego kościoła w Mikaszewiczach dekanatu tuninieckiego, województwa poleskiego, powiatu tuninieckiego, diecezji Pińskiej, sporzqdzony dnia 1 grudnia 1938 roku przez ks. Jana Karnickiego.

Licząca zaledwie kilkanaście lat do wybuchu wojny w 1939 roku parafia Mikaszewicze. Jej ostatni proboszcz ks. Urban Filipiak po tzw. repatriacji do Polski został proboszczem w Wiomie. Tam dopisał do sporządzonego w grudniu 1938

* Waldemar W. Żurek SDB - dr hab. historii Kościoła, prof KUL; dyrektor Ośrodka Archiwów Bibliotek i Muzeów Kościelnych KUL; e-mail: zurek@kul.pl

${ }^{1}$ Mikaszewicze, w: Stownik Geograficzny Królestwa Polskiego, t. VI, Warszawa 1885, s. 393. 
roku inwentarza parafii Mikaszewicze lakoniczne, lecz bardzo ważne wydarzenia z czasów drugiej wojny światowej oraz ekspatriację Polaków w nowe granice kraju po 1945 roku.

$* * *$

\section{Historia kościoła}

Mikaszewicze były kiedyś małą osadą poleską. Budowa kolei około r. 1900, nieduży tartaczek zaczynają zgromadzić większe rezerwy ludzi z odleglejszych stron - mieszkańcy bowiem miejscowych okolic niechętnym okiem patrzyli na wprowadzane innowacje i nie chcieli pracować. W r. 1908 powstaje fabryka dykty, a tartak powiększono wznosząc murowane ściany. W r. 1911 tartak spalono, aż w r. 1923 zostaje odbudowany. Fabryka dykty w r. 1921, dnia 2 kwietnia zostaje całkowicie przez bolszewików zdewastowana, uchodząc bowiem z Mikaszewicz przez rzekę Słucz, która miała się stać na mocy traktatu Ryskiego nową granicą między Polską i Rosją, zabrali to, co dało się wywieźć i miało wartość. Uruchomiona fabryka w r. 1925 na nowo odbudowana, jak też i tartak zaczęła ściągać ludzi poszukujących pracy - a więc proletariuszy przede wszystkim. Początkowo pracowało około 300 robotników - a w roku zaś 1938 pracuje około 1000 . Z małego osiedla tworzy się dość duże miasteczko wraz z kolonią robotniczą, o znacznej mniejszości polskiej i katolickiej. Rozrost fabryki - zadecydował o potrzebie stworzenia osobnej parafii i zbudowania kościoła. Okoliczne wsie jak Rudnia, Morszczynowicze i Zaprosie w czasie niewoli zatracają wiarę ojców i przechodzą na prawosławie. Przy wierze katolickiej pozostaje nieliczna garstka kurczowo się trzymająca wiary, która jednak z braku oświaty religijnej zatraca swoje oblicze nadprzyrodzone, pokrywają się ciemnym zabobonem. Najmniej odporną okazała się wieś Sytnica, tak że ani jedna rodzina nie utrzymała się przy wierze katolickiej (dziś siedlisko komunizmu i bandytyzmu). Powyższe wsie należą kolejno do parafii Pińskiej, Dawidgródzkiej, ostatni zaś Łachewskiej. Proboszczowie starają się od czasu do czasu zaglądać do Mikaszewicz, odprawiają nabożeństwa w izbie robotniczej, potem w szkole. W roku 1923 wizytuje Mikaszewicze ks. biskup Zygmunt Łoziński ówczesny biskup miński rezydujący w Nowogródku. Wtedy

${ }^{2}$ Bp Łoziński Zygmunt (1870-1932) - studia teologiczne ukończył w Petersburgu, święcenia kapłańskie przyjął w 1895 roku. Pracował jako wykładowca w seminarium i opiekun młodzieży akademickiej. W latach 1898-1900 został skazany na banicję, przebywał w klasztorze karnym w Agłomie na Łotwie. Następnie pracował w duszpasterstwie: w Smoleńsku, Tule, Rydze, Kalwarii koło Mińska (proboszcz). Usunięty z Mińska za przyjmowanie unitów do Kościoła katolickiego, podjął wykłady w Akademii Duchownej Petersburgu i kontynuował studia biblijne (Monachium, Rzym, Jerozolima, Rzym). W czasie I wojny światowej był kapelanem w obozach jeńców wojennych. W 1917 roku został ordynariuszem reaktywowanej diecezji mińskiej. Sakrę biskupią przyjął w 1918 roku w Warszawie. Po wejściu w grudniu 1918 roku Armii Czerwonej do Mińska ukrywał się. Powrócił do miasta w sierpniu 1919 roku. Jeszcze w tym roku, po proklamowaniu Białoruskiej SRR, został aresztowany i więziony w Moskwie. Na mocy traktatu ryskiego 1921 roku zwolniony i udał się do Nowogródka, gdzie organizował życie religijne w polskiej części diecezji mińskiej. W 1925 roku został ordynariuszem utworzonej diecezji pińskiej. Zmarł w opinii świętości, jego 
to p. Zygmunt Baranowski sekretarz firmy „Agahell i Olza', przejęty wdzięcznością Panu Bogu po odbytej spowiedzi przed pasterzem rzucił myśl budowy kościoła, biorąc trud na swoje przede wszystkim barki. Stworzono komitet budowy kościoła, w którym Zygmunt Baranowski zostaje vice-prezesem, a członkami urzędnicy kolejowi i celni. Zaczęto akcję zbiórkową. Zebrane pieniądze które po przewalutowaniu z marek wyniosły około 800 zł złożono w Łunińcu w Oddziale Banku Handlowo-Przemysłowego. Po bankructwie otrzymano zaledwie $168 \mathrm{zl}$ i resztę akcjami. Pozostałe tarcie w łonie Komitetu całą akcję paraliżuje. Aż w roku 1927 Biskup Ordynariusz Piński Zygmunt Łoziński eryguje w Mikaszewiczach parafię. Na pierwszego proboszcza mianuje ks. Pawła Stepka, który jednocześnie pełni obowiązki prefekta szkół. Ks. P[aweł] Stepka musiał pracować w niebywale ciężkich warunkach. Nabożeństwa w niedziele i święta odprawia w szkole, mieszka w wynajętym przez parafię domku, w którym mieści się też $\mathrm{i}$ kapliczka; a najbardziej rani serce kapłańskie obojętność religijna katolików, bo z łask Bożych korzysta tylko garstka. Myśl budowy kościoła odżywa na nowo. Zorganizowano Komitet Budowy Kościoła: 1) Prezes ks. Paweł Stepek, 2) Vice-prezes Zygmunt Baranowicz, 3) Skarbnik Jan Sawicki, 4) Członkowie: Maurycy Villiot, Mikołaj Szokarew, Józef Leszczyński, Tomasz Skrzela, Franciszek Orłowski, Antoni Okinczyc.

Plac pod budowę kościoła ofiarowali sukcesorowie Agarkowa, którzy w Mikaszewiczach i okolicy mieli olbrzymie posiadłości ziemskie, tartak i fabrykę dykty w Mikszewiczach. Jakkolwiek sukcesorowie byli wyznania prawosławnego, to jednak doceniali wartość Kościoła, oraz jego pracę w podnoszeniu poziomu moralnego ludności. Gdy cała majętność przechodziła w ręce Spółki Akcyjnej „Olza”, Agarkowie zastrzegli 1 dziesięcinę ziemi dla Kościoła. Wobec tego, że zaofiarowana dziesięcina ziemi wyznaczona została poza wsią Mikaszewicze, przy drodze prowadzącej do Zaprosia, a chodziło, żeby kościół stanął w centrum, Komitet zwrócił się do dyrektora Spółki Akcyjnej „Agahell” z prośbą o zamianę na plac dogodniejszy. Dyrektor Samuel Gomberg przychylił się do prośby i wyznaczył plac pod budowę kościoła w centrum pomiędzy miasteczkiem i kolonią robotniczą, uprzednio czyniąc zamianę z włościanami wsi Mikaszewicze. Ks. Paweł Stepek ${ }^{3}$ był zdania, żeby kościół postawić przy cmentarzu prawosławnym, przy dworcu kolejowym. Ale w tym czasie ks. [Paweł] Stepek zostaje przeniesio-

proces beatyfikacyjny rozpoczęto w 1957 roku w Rzymie. J. Misiurek, Eoziński Zygmunt, w: Encyklopedia Katolicka (dalej: EK), t. 11, Lublin 2006, kol. 554-555.

${ }^{3}$ Ks. Stepek Paweł (1877-1953) - kapłan diecezji pińskiej. Urodził się w Haczkowie, w 1912 roku przyjął święcenia kapłańskie. Był pierwszym proboszczem w Mikaszewiczach (i nauczycielem religii), gdzie poczatkowo odprawiano w wynajętym domu. Od 3 czerwca 1934 roku do 19 września 1934 roku pełnił obowiązki, a następnie był proboszczem parafii Podwyższenia Świętego Krzyża w Hajnówce, erygowanej przez biskupa wileńskiego w 1923 roku, jako drugi z rzędu jej proboszcz. http://www.encyklopedia.puszcza-bialowieska.eu/index.php?dzial=haslo\&id=703 (dostęp: 28.02.2016). 
ny do Hajnówki, a do Mikaszewicz biskup ordynariusz wyznaczył ks. Siudzińskiego Wincentego ${ }^{4}$.

Architekt Przybysławski sporządził projekt kościoła w stylu dość dziwnym, bo była to mieszanina stylów gotyckiego z romańskim. Województwo poleskie w Brześciu zatwierdziło projekt dopiero po uzupełnieniach dokonanych przez inż. Czerniewskiego Piotra z Mikaszewicz i inż. Papieskiego, architekta wojewódzkiego na sumę $54.000 \mathrm{zł}$.

Sprawą finansową gorliwie zajął się Zygmunt Baranowski, ściągnięcie potrzebnej gotówki wziął na swoje barki i wywiązał się z zadania bardzo dobrze.

Tymczasem ks. W[incenty] Siudziński zostaje przeniesiony do Łachwy a do Mikaszewicz zostaje mianowany ks. Wieliczko Bronisław.

Komitet na budowę kościoła otrzymał od wojewody poleskiego Kostki-Biernackiego 3.200 zł. Biskup ordynariusz Kazimierz Bukraba ${ }^{5}$ ofiarował 1.000 zł, podstawą zaś było dobrowolne opodatkowanie się przede wszystkim robotników i urzędników firmowych, i innych parafian, a nawet i prawosławnych. Wsie okoliczne, nawet katolicy w nich zamieszkujący do budowy kościoła odnosili się obojętnie, skąpiąc na ten cel wydatków pieniężnych, dali tylko część furmanek do wożenia materiałów. Natomiast ludność robotnicza okazała się niezwykle ofiarną, dając ofiary pieniężne i ofiarując swoją pracę. Zygmunt Baranowski swoim przykładem przyświecał, chwytając nieraz za łopatę w swoje ręce, pracował jak najprostszy robotnik. Dyrektor inż. Samuel Gomberg będąc protestantem wydatnie poparł budowę kościoła i moralnie i pieniężnie.

W roku 1935 założono fundamenta a w roku 1936 stanęła świątynia pod tytułem Królowej Korony Polskiej. Dnia 11 października dziekan łuniniecki dokonuje poświęcenia kościoła. Stanęła świątynia piękna murowana z białej cegły częściowo sprowadzonej w Wołkowyska od Kosberga, a częściowo z Bud k. Lenina. Części żelazne wykonali majstrowie z warsztatów firmowych.

${ }^{4}$ Ks. Siudziński Wincenty - kapłan diecezji pińskiej. Urodził się w 1899 roku. Święcenia kapłańskie przyjął w 1933 roku. Od 1 września 1934 do 15 lipca 1935 roku pełnił obowiązki proboszcza w parafii Mikaszewicze oraz był nauczycielem religii w parafii. Od 1938 roku rezydował w Parafii Podwyższenia Świętego Krzyża w Baranowiczach i pełnił obowiązki prefekta prywatnych szkół średnich. Spis kościołów i duchowieństwa diecezji pińskiej w R. P. 1935, Pińsk 1935, s. 128, 177.

${ }^{5}$ Bp Bukraba Kazimierz (1885-1946). Urodził się w Grodnie. Teologię studiował w Petersburgu, następnie w Insbrucku. Święcenia kapłańskie przyjął dnia 2 II 1909 roku w Krakowie. Pracował w Mińsku Litewskim jako wikariusz i prefekt szkół, od 1912 roku był proboszczem w Pińsku i rektorem kościoła św. Karola Boromeusza, od 1917 roku proboszczem w Nowogródku, od 1928 roku w Brześciu. W czasie pierwszej wojny światowej był kilkakrotnie więziony jako zakładnik. Mianowany biskupem pińskim dnia 10 VII 1932 roku. Konsekrację biskupią przyjął dnia 21 VIII 1932 roku w Wilnie. Rządy diecezją objął dnia 28 VIII 1932 roku. Był drugim ordynariuszem diecezji pińskiej. W 1934 roku ogłosił statuty synodu diecezjalnego, kilkakrotnie wizytował diecezję, rozbudował sieć parafialną i utworzył 2 nowe dekanaty, sprowadził do pracy w diecezji zakony. Po wybuchu II wojny światowej musiał opuścić stolicę diecezji. Rezydował we Lwowie 1939, Warszawie 1942 i od 1944 roku w Łodzi, gdzie zmarł. A. Petrani, Bukraba Kazimierz, EK, t. 2, Lublin 1985, kol. 1189-1190. 
Ołtarz główny wybudował własnym kosztem dyrektor Samuel Gomberg. Mensa ołtarzowa murowana, inne części z dębowej dykty z figurą Matki Boskiej. Dnia 18 lipca 1937 roku biskup Kazimierz Bukraba dokonał konsekracji kościoła. Zygmunt Baranowski za ofiarną pracę przy budowie kościoła został odznaczony Krzyżem Papieskim „Pro Ecclesiae et Pontificae”. Oddając sprawiedliwość muszę podkreślić, że Zygmunt Baranowski i jego małżonka Elżbieta Baranowska dotychczas dużo dla kościoła zrobili troszcząc się także o utensilia kościelne. Komitet Budowy istnieje nadal, gdyż wziął sobie za zadanie wybudowanie plebanii. Mikaszewicze dnia 1 grudnia 1938 r.ks. Jan Karnicki ${ }^{7}$

\footnotetext{
${ }^{6}$ Krzyż Papieski „Pro Ecclesia et Pontificae” (Za Zasługi dla Kościoła i Pontyfikatu) - medal papieski ustanowiony w 1887 roku jako odznaczenie honorowe dla osób świeckich o nienagannej postawie moralnej, zaangażowanych w życie wspólnoty Kościoła, szczególnie zasłużonych dla Kościoła katolickiego i kultury chrześcijańskiej. Informacje o ustanowieniu medalu pojawiły się w Rzymie 31 grudnia 1887 roku w związku z rozpoczęciem przygotowań do Złotego Jubileuszu Kapłaństwa i 10-lecia Pontyfikatu papieża Leona XIII, gdy zapowiedziano, że osoby zaangażowane w organizację tych uroczystości zostaną uhonorowane specjalnym medalem papieskim. Medal zawierał wizerunek ówczesnego papieża i inskrypcję: LOE XIII P.M.ANN.X. Produkowano go w trzech wersjach: złotej, srebrnej i brązowej. W 1908 roku papież Pius X zmodyfikował formę medalu, wykluczając egzemplarze złote. Papież Paweł VI zamiast wizerunku papieża polecił umieścić podobizny apostołów Piotra (z kluczami w ręku) i Pawła (z Ewangelia i mieczem) oraz wykonywać go z mosiądzu i aluminium, co miało symbolizować barwy flagi watykańskiej. Odtąd w dolnej części krzyża orderowego umieszcza się łacińskie imię aktualnego papieża, a w górnej, obok poprzedniego napisu PRO ECCLESIA et PONTIFICE, herb papieski. Ma postać krzyża greckiego, zawieszany jest na wstążce żółto-białej. Obecnie zalicza się do orderów papieskich i jest przyznawany przez papieża na wniosek ordynariusza diecezji. J. B. Stachowiak, Pro Ecclesia et Pontifice, EK, t. 16, Lublin 2012, kol. 409.

${ }^{7}$ Ks. Karnicki Jan (1908-1970) - ksiądz z diecezji pińskiej, kapelan WP i Armii Krajowej, po II wojnie światowej organizator i pierwszy proboszcz parafii w Miastku. Urodził się w Lucynie (obecnie Łotwa). Był synem Antoniego i Magdaleny z domu Michalkiewicz. Ukończył seminarium duchowne w Pińsku i dnia 18 IV 1935 roku przyjął święcenia kapłańskie. Pracował jako wikary w Rubieżewiczach 1935-1938, pełnił obowiązki proboszcza w Mikaszewiczach 1938-1939. W 1939 roku otrzymał nominację na kapelana rezerwy i pełnił funkcję administratora parafii w Słonimiu. Brał udział w wojnie obronnej 1939 roku. W miejscowości Krzywda dostał się do niewoli niemieckiej, skąd wkrótce zbiegł. Po przejściu do partyzantki otrzymał pseudonim „Miś”. Był kapelanem w AK. Ukrywając się na terenach podwarszawskich, był m.in. pomocnikiem proboszcza, kapelanem sióstr urszulanek w Miedzeszynie. Od sierpnia 1945 roku podjął pracę duszpasterską na Ziemiach Odzyskanych. Do 30 września 1962 roku był proboszczem w Miastku. Zorganizował od podstaw życie religijne na terenie dawnego powiatu miastkowskiego. Przystosował do kultu katolickiego, poświęcił i nadał tytuły kościołom w Barcinie, Biesowicach, Kołczygłowach, Płocku, Sępnie Wielkim, Kołtkach, Wałdwie, Kramarzynach, Kępicach, Świerzynie, Miłocicach, Dretyniu. Pełnił funkcję wicedziekana dekanatu bytowskiego, do którego należało wówczas Miastko. Dnia 30 września 1962 roku powrócił do rodzinnej diecezji pińskiej i rozpoczął pracę w Wyszkach. W latach 19651970 był proboszczem w Ostrożanach, gdzie zmarł i został pochowany na cmentarzu parafialnym. W 2010 roku z inicjatywy księży pochodzących z Miastka powołano komitet dla sprowadzenia ciała ks. Jana Karnickiego do Miastka. Powtórny pochówek jego odbył się 9 kwietnia 2011 roku na cmentarzu komunalnym w Miastku, gdzie ks. Karnicki spoczął w grobowcu razem ze swoim ojcem - Antonim (pochowany w Miastku w lutym 1962). https://pl.wikipedia.org/wiki/Jan_Karnicki (dostęp: 28.02.2017).
} 


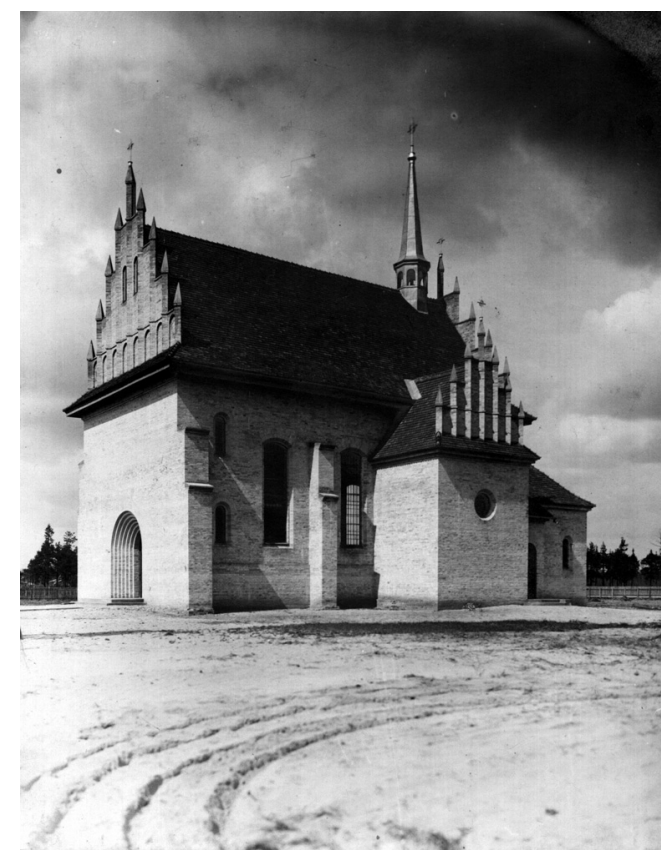

Fot*. 1. Widok zewnętrzny kościoła parafialnego pw. Matki Bożej Królowej Korony Polskiej w Mikaszewiczach, 1936 r.

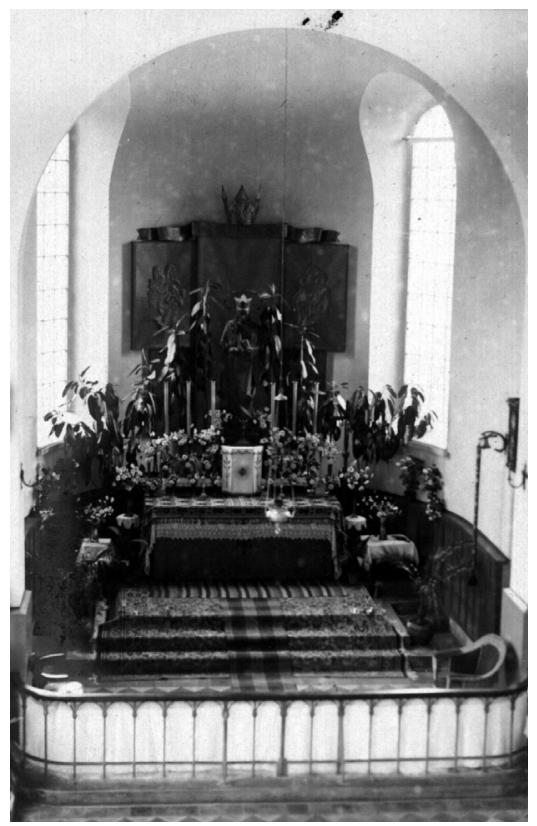

Fot. 2. Ołtarz główny w kościele parafialnym pw. Matki Bożej Królowej Korony Polskiej w Mikaszewiczach, 1936 r.

* Wszystkie zdjęcia pochodzą ze zbiorów Archiwum Diecezjalnego w Drohiczynie. 


\begin{tabular}{|l|l|c|}
\hline L.p. & Nazwa przedmiotu & Ilość \\
\hline 1 & Ołtarz wielki z figurą Matki Bożej Królowej Korony Polskiej & 1 \\
\hline 2 & Ołtarz jesionowy (prowizoryczny) & 1 \\
\hline 3 & Lichtarze żelazne & 6 \\
\hline 4 & Lichtarze metalowe & 4 \\
\hline 5 & Lichtarze gotyckie & 2 \\
\hline 6 & Kandelabrya (po 3 świece) & 2 \\
\hline 7 & Lichtarze drewniane & 6 \\
\hline 8 & Lichtarze małe & 4 \\
\hline 9 & Lampa wieczna & 1 \\
\hline 10 & Kropielnica metalowa & 1 \\
\hline 11 & Puszka metalowa na wodę do ołtarza & 1 \\
\hline 12 & Miedniczka metalowa do chrztu & 4 \\
\hline 13 & Dzbanuszek metalowy do chrztu & 2 \\
\hline 14 & Ampułki & 1 \\
\hline 15 & Tacki do ampułek & 1 \\
\hline 16 & Naczynka do olejów św. & 1 \\
\hline 17 & Turybularz & 1 \\
\hline 18 & Lódka z łyżeczką do kadzidła & 1 \\
\hline 19 & Kociołek do wody święconej & 1 \\
\hline 20 & Kropidło metalowe & 1 \\
\hline 21 & Portatyle & \\
\hline 22 & Monstrancja (jedna pęknięta) & 1 \\
\hline & & 1 \\
\hline
\end{tabular}

a Kandelabr - duży, stojący, kilkuramienny świecznik. Początkowo prosty wykonywany z drewna, trzciny, gliny lub metalu, później z brązu, marmuru, alabastru i z ozdobami. Podstawę - stopę kandelabra tworzą trzy zwierzęce stopy (często łapy lwa), ozdobione formami (stopami) ludzkimi lub zwierzęcymi. Na górze posiada płaskie naczynie. Kandelabry zdobiły świątynie, pałace, łaźnie publicznie.

b Trybularz lub kadzielnica ( łac. Turibulum lub Thuribulum) - naczynie do którego na rozżarzone węgle sypie się kadzidła, służące do okadzania: ołtarza, darów ofiarnych w czasie Mszy Świętej, Najświętszego Sakramentu, Ewangeliarza, krzyża, uczestników liturgii, figur. Wykonany jest z metalu, umocowane na łańcuszkach i zamykany przykrywką.

${ }^{c}$ Portatyl (łac. altare portatile) - wykonywane od VII wieku małe, przenośne ołtarzyki, głównie metalowe lub z kości słoniowej, używane w czasie podróży do sprawowania liturgii mszalnej. W późniejszym okresie ołtarz ten został zastąpiony zestawem miniaturowych sprzętów mszalnych wykorzystywanych przez kapelanów wojskowych lub duchownych do udzielania sakramentu chorych, tzw. wiatyku. Portatyl musiał być wykonany z jednolitej bryły kamienia na tyle grubej, aby w środku znalazło się miejsce na relikwie, a na nim kielich i hostia, a także puszka z komunikantami do konsekracji. 


\begin{tabular}{|c|c|c|}
\hline 23 & Puszka & 1 \\
\hline 24 & Kielichy & 3 \\
\hline 25 & Patena od infirmos & 1 \\
\hline 26 & Naczynie do olejów od infirmorum & 1 \\
\hline 27 & Krucyfiksy & 4 \\
\hline 28 & Krzyże procesjonalne & 1 \\
\hline 29 & Pudełko na hostie & 1 \\
\hline 30 & Przyrząd do zapalania świec & 1 \\
\hline 31 & Flakony na kwiaty & 7 \\
\hline 32 & Fotel trzcinowy & 1 \\
\hline 33 & Klęczniki & 1 \\
\hline 34 & Konfesjonał klęcznikowy & 1 \\
\hline 35 & Szafa $\mathrm{z}$ dykty na paramenta & 1 \\
\hline 36 & Szafa sosnowa do kancelarii & 1 \\
\hline 37 & Etażerka sosnowa na akta parafialne & 1 \\
\hline 38 & Fisharmonia & 1 \\
\hline 39 & Kancjonał & 1 \\
\hline 40 & Rytuał duży & 1 \\
\hline 41 & Rytuał mały & 1 \\
\hline 42 & Rytuał mały do chorych & 1 \\
\hline 43 & Mszały & 2 \\
\hline 44 & Mszał żałobny & 1 \\
\hline 45 & Obraz „Ecce homo” (oleodruk) & 1 \\
\hline 46 & Obraz Matki Boskiej Częstochowskiej (oleodruk) & 1 \\
\hline 47 & Ornaty białe & 3 \\
\hline 48 & Ornaty zielone & 2 \\
\hline 49 & Ornaty czerwone & 3 \\
\hline 50 & Ornaty czarne & 2 \\
\hline 51 & Ornat fioletowy & 2 \\
\hline 52 & Tuwalnia $^{\mathrm{d}}$ adamaszkowa & 1 \\
\hline 53 & Sukienka na puszkę & 1 \\
\hline 54 & Bursa do chorych & 1 \\
\hline 55 & Stuła biała haftowana & 1 \\
\hline 56 & Sztandary czerwono-białe (małe) & 2 \\
\hline 57 & Poduszki do procesji & 2 \\
\hline
\end{tabular}

d Tuwalnia (wł.) - rodzaj ręcznika, przez który kapłan trzyma monstrancję. 


\begin{tabular}{|c|c|c|}
\hline 58 & Poduszki pod mszał & 2 \\
\hline 59 & Antepedium ${ }^{\mathrm{e}}$ czerwone, sukienne & 1 \\
\hline 60 & Pokrowce na ołtarze & 3 \\
\hline 61 & Dywan na stopnie & 1 \\
\hline 62 & Alby & 5 \\
\hline 63 & Komże duże & 5 \\
\hline 64 & Komże małe & 6 \\
\hline 65 & Obrusy na ołtarze & 5 \\
\hline 66 & Kapy białe & 2 \\
\hline 67 & Kapy czerwone & 1 \\
\hline 68 & Kapy fioletowe & 1 \\
\hline 69 & Korporały & 12 \\
\hline 70 & Puryfikaterze & 15 \\
\hline 71 & Palki & 8 \\
\hline 72 & Ręczniki & 20 \\
\hline 73 & Humerały & 9 \\
\hline 74 & Paski & 3 \\
\hline 75 & Serwety płócienne & 2 \\
\hline 76 & Kanony $^{\mathrm{f}}$ & $\begin{array}{c}2 \\
\text { komplety }\end{array}$ \\
\hline 77 & Portret Piusa XI (do kancelarii) & 1 \\
\hline 78 & Portret bpa [Zygmunta] Łozińskiego & 1 \\
\hline 79 & Portret bpa [Kazimierza] Bukraby & 1 \\
\hline 80 & Stuła (dwustronna) & 1 \\
\hline 81 & Poduszka pod mszał, czarna & 1 \\
\hline 82 & Latarnia od infirmos & 1 \\
\hline 83 & Taca pleciona & 1 \\
\hline 84 & Kilim & 1 \\
\hline 85 & Baldachim $\mathrm{z}$ brokatu & 1 \\
\hline 86 & Latarnia procesjonalna & 4 \\
\hline
\end{tabular}

e Antependium, antepedium (od łac. ante pedes przed stopami) - zasłona ścianki frontowej ołtarza.

${ }^{\mathrm{f}}$ Kanony - trzy tablice oprawne na dawnych ołtarzach, z których jedna, największa, umieszczana była na środku, a dwie mniejsze po bokach ołtarza. Środkowa tablica zawierała modlitwy odmawiane w czasie Mszy Świętej podczas ofiarowania. Tablica po prawej stronie ołtarza, gdzie kapłan obmywał ręce, zawierała Psalm 50 (Lavabo Domine...), a tablica z lewej (tzw. ostatnia) - Ewangelię wg św. Jana. Po reformie liturgii Soboru Watykańskiego II zniesione zostały kanony. 


\begin{tabular}{|l|l|l|}
\hline 87 & Dzwon & 1 \\
\hline 88 & Dzwonki harmonijne & 2 \\
\hline 89 & Figurka Pana Jezusa Zmartwychwstałego & 1 \\
\hline 90 & Patena do wydawania Komunii świętej & 1 \\
\hline 91 & Chorągiew procesjonalna czerwona & 1 \\
\hline 92 & Umbraculum ${ }^{g}$ & 1 \\
\hline 93 & Klęcznik dębowy & 1 \\
\hline 94 & Zasłonki białe do krat & 1 \\
\hline 95 & Chorągiew & 1 \\
\hline 96 & Chorągiew biała & 1 \\
\hline 97 & Szopka (24 figurki) & 1 \\
\hline 98 & Szafka na Oleje św. & 1 \\
\hline 99 & Stolik pod szafkę z Olejami św. & 3 \\
\hline 100 & Obrus na stół w zakrystii & 2 \\
\hline 101 & Komże nowe & 1 \\
\hline 102 & Alby & 1 \\
\hline 103 & Obrus na ołtarz & 1 \\
\hline 104 & Obrus na ołtarz mały & 3 \\
\hline 105 & Ornat biały (stary) & 1 \\
\hline 106 & Ornat czarny (stary) & 1 \\
\hline 107 & Ręczniki & 1 \\
\hline 108 & Humerały & 1 \\
\hline 109 & Pasy & 1 \\
\hline & & 1 \\
\hline
\end{tabular}

\section{Mikaszewicze 2 IX 1938 rok. Zdałem. Ks. Bronisław Wieliczko ${ }^{8}$}

\section{Przyjąłem. Ks. [Jan] Karnicki ${ }^{9}$}

\section{Byłem obecny ks. F[abian] Poczobutt-[Odlanicki] ${ }^{10}$ dziekan łuniniecki}

g Umbraculum (łac. miejsce ocienione) - parawan na stojaku z emblematem JHS, służący do zasłaniania monstrancji z Najświętszym Sakramentem podczas nabożeństw liturgicznych, np. w czasie głoszenia kazania.

${ }^{8}$ Ks. Wieliczko Bronisław, urodził się 13 XI 1903 roku w Wojdziewiczach koło Wołożyna (obecnie Białoruś). Święcenia kapłańskie przyjął 15 IV 1933 roku w Pińsku, następnie pracował w Pińsku (1933-1934). Tuż przed wojną i w czasie II wojny światowej duszpasterzował w Baranowiczach aż do momentu ekspatriacji. Na Ziemie Odzyskane przybył 25 XI 1949 roku. Był proboszczem w parafii Lipka Krajeńska w diecezji gorzowskiej. W. Urban, Duszpasterska siejba kapłanów-repatriantów na ziemiach odzyskanych w latach 1945-1970, Wrocław 1972, s. 111.

${ }^{9}$ Zob. przypis $\mathrm{nr} 6$.

${ }^{10}$ Ks. Poczobutt-Odlanicki Fabian (1896-1944) - dziekan i proboszcz parafii Łuniniec koło Pińska. Święcenia kapłańskie otrzymał dnia 12 VI 1921 roku w Wilnie. W latach 1921-1924 był proboszczem w Kywinie, w latach 1926-1932 prefektem Gimnazjum im. A. Mickiewicza w Prużanie i wikariuszem w parafii oraz kierownikiem Sodalicji Mariańskiej, w latach 1933-1934 proboszczem 


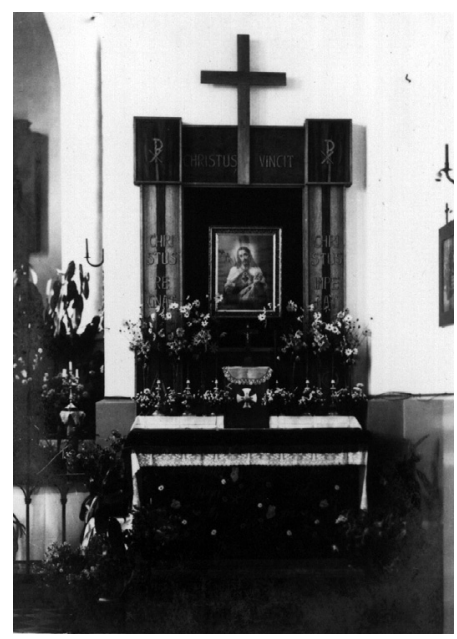

Fot. 3. Mikaszewicze 1942 . Obraz boczny Najświętszego Serca Jezusowego, ufundowany w grudniu 1942 roku przez parafian za staraniem ks. proboszcza Urbana Filipiaka, jako wotum wdzięczności za ocalenie mieszkańców Mikaszewicz i okolicy, poświęcony dnia 20 XII 1942 roku.

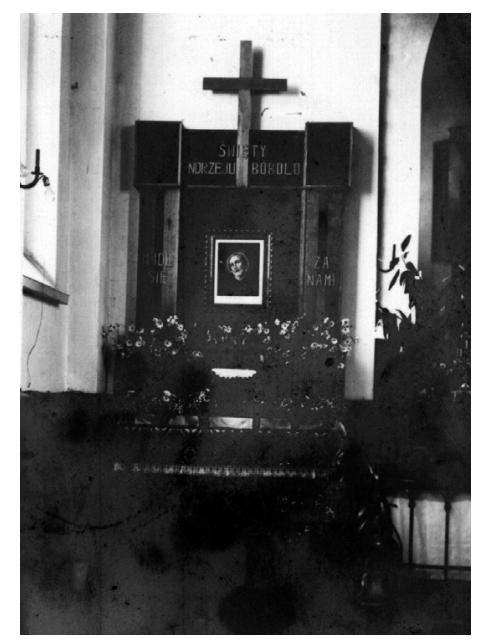

Fot. 4. Mikaszewicze 1943. Obraz boczny ku czci św. Andrzeja Boboli, zbudowany przez parafian ku czci patrona Polesia ze specjalnym oddaniem się jego opiece w czasach wojennych, poświęcony dnia 6 czerwca 1943 przez proboszcza - ks. Urbana Filipiaka.

w Śledzianowie i dekanalnym wizytatorem religii. W 1934 roku przeniesiony został na proboszcza do Larczy Kartuskiej, od 1937 roku był proboszczem i dziekanem w Łunińcu. W okresie okupacji był delegatem Rządu Londyńskiego na Polesie. Został zastrzelony w Koźlakiewiczach koło Pińska dnia 4 VII 1944 roku, za organizowanie pomocy Żydom i partyzantom radzieckim. Pochowany został za kaplicą cmentarną w Pińsku. Ekshumowany po wojnie i pochowany na cmentarzu katolickim w Pińsku. W. Jacewicz, Martyrologium polskiego duchowieństwa rzymskokatolickiego pod okupacja hitlerowska w latach 1939-1945, Warszawa 1977, s. 278; Niech świadectwo nie będzie zapomniane, opr. L. Michajlik, Grodno 2000, s. 75. 


\begin{tabular}{|c|c|c|c|c|c|}
\hline \multirow[t]{2}{*}{ L.p. } & \multirow[t]{2}{*}{ Nazwa przedmiotu } & \multirow[t]{2}{*}{ Ilość } & \multicolumn{2}{|c|}{ Wartość } & \multirow[t]{2}{*}{ Uwagi } \\
\hline & & & zł. & gr. & \\
\hline \multicolumn{6}{|c|}{ III. Wnętrze kościoła } \\
\hline 1 & $\begin{array}{l}\text { Ołtarz wielki z dębowej dykty w stylu nowocze- } \\
\text { snym }\end{array}$ & 1 & & & $\begin{array}{l}\text { ofiara p. dyrek- } \\
\text { tora Gomberga } \\
\text { Samuela } 1937 \mathrm{r} \text {. }\end{array}$ \\
\hline 2 & $\begin{array}{l}\text { Tabernakulum dębowe wysłane adamaszkiem } \\
\text {,dostosowane do stylu ołtarza, drzwiczki, poje- } \\
\text { dyncze dębowe gładkie, zamek wewnętrzny }\end{array}$ & 1 & & & \\
\hline 3 & $\begin{array}{l}\text { Statua Królowej Korony Polskiej z gipsu, ciem- } \\
\text { no malowana; } \\
\text { Odlew Zwiastowania N.M.P.; } \\
\text { Odlew zdjęcia z Krzyża oba z gipsu ciemno ma- } \\
\text { lowane; } \\
\text { Korona i wstęga z miedzi na szczypce ołtarza }\end{array}$ & $\begin{array}{l}1 \\
1 \\
1 \\
1\end{array}$ & & & \\
\hline 4 & $\begin{array}{l}\text { Mensa marmurowa; } \\
\text { Antepedium dębowe gładkie; } \\
\text { Stopni } 3 \text { z cementu }\end{array}$ & $\begin{array}{l}1 \\
1\end{array}$ & 5000 & 00 & \\
\hline 5 & $\begin{array}{l}\text { Ołtarz w kaplicy, prowizoryczny, dębowy z } 2 \\
\text { szufladami na bieliznę kościelną; } \\
\text { Mensa drewniana; } \\
\text { Portatyl w dobrym stanie; } \\
\text { Antepedium z czerwonego sukna; } \\
\text { Tabernakulum dębowe }\end{array}$ & $\begin{array}{l}1 \\
1 \\
1 \\
1 \\
1\end{array}$ & 100 & 00 & $\begin{array}{l}\text { staraniem p. } \\
\text { Baranowickie- } \\
\text { go Z. zrobiony } \\
\text { w } 1929 \mathrm{r} \text {. }\end{array}$ \\
\hline 6 & $\begin{array}{l}\text { Chrzcielnica: } \\
\text { - stół dębowy } \\
\text { - szafka dębowa do przechowywania Olejów św. } \\
\text { - naczynie do przechowywania wody chrzcielnej }\end{array}$ & 1 & $\begin{array}{c}40 \\
5\end{array}$ & $\begin{array}{l}00 \\
00\end{array}$ & \\
\hline 7 & $\begin{array}{l}\text { Kazalnica prowizoryczna drewniana umieszczo- } \\
\text { na w prezbiterium }\end{array}$ & 1 & & & \\
\hline 8 & Konfesjonał prowizoryczny drewniany & 1 & & & \\
\hline 9 & $\begin{array}{l}\text { Balustrada żelazna, z blatem dębowym i lnia- } \\
\text { nym obrusem }\end{array}$ & 1 & & & \\
\hline 10 & Chór murowany z balustradą murowaną & 1 & & & \\
\hline 11 & Fisharmonia 6-registrowa, stara & 1 & 926 & 00 & \\
\hline 12 & $\begin{array}{l}\text { Ołtarz Najśw[iętszego] Serca Jezusowego; } \\
\text { Drzewo dębowe - dar fabryki; } \\
\text { Obraz, krzyż Jerozolimski, antepedium - dar ks. } \\
\text { Urbana Filipiaka }\end{array}$ & 1 & & & $\begin{array}{c}\text { zbudowany } \\
\text { przez parafian } \\
\text { w } 1942 \text { r., } \\
\text { robotę ołtarza } \\
\text { wykonali pa- } \\
\text { nowie: Józef } \\
\text { Wieczorek } \\
\text { i Feliks Kublik } \\
\text { z Warszawy }\end{array}$ \\
\hline
\end{tabular}




\begin{tabular}{|c|c|c|c|c|c|}
\hline 13 & $\begin{array}{l}\text { Ołtarz św. Andrzeja Boboli; } \\
\text { Drzewo dębowe - dar fabryki; } \\
\text { Obraz z kościoła lenińskiego; } \\
\text { Antepedium - dar panów: Piotra Mamczyca i } \\
\text { Józefa Brudho-Stempkowskiego; } \\
\text { Plusz pod obraz - dar p. Wiery Strach; } \\
\text { Dywan na stopnie - dar parafian z Zaprosia; } \\
\text { Tabernakulum - dar pana Szulca Andrzeja }\end{array}$ & 1 & & & $\begin{array}{c}\text { zbudowany } \\
\text { przez parafian, } \\
\text { robotę ołtarza } \\
\text { wykonali: } \\
\text { panowie Józef } \\
\text { Wieczorek, } \\
\text { Witold Kar- } \\
\text { bowski i An- } \\
\text { drzej Jaworski } \\
\text { z Warszawy }\end{array}$ \\
\hline \multicolumn{6}{|c|}{ IV. Zakrystia } \\
\hline 1 & $\begin{array}{l}\text { Zakrystia z prawej strony kościoła murowana; } \\
\text { - okien z ramami żelaznymi i jasnymi szybami; } \\
\text { - drzwi fornirowanych z dykty z wewnętrznymi } \\
\text { żelaznymi zamkami; } \\
\text { - posadzka nowa; } \\
\text { - przedsionek }\end{array}$ & $\begin{array}{l}1 \\
3 \\
2\end{array}$ & & & \\
\hline 2 & $\begin{array}{l}\text { Szafa dębowa z forniru do przechowywania pa- } \\
\text { ramentów }\end{array}$ & 1 & & & $\begin{array}{l}\text { staraniem Bara- } \\
\text { nowickiego Z. } \\
\text { i Szokarewa M. }\end{array}$ \\
\hline 3 & Szafka dębowa na kielichy & 1 & & & \\
\hline 4 & Klęcznik dębowy ciemny & 1 & & & \\
\hline 5 & Stół na paramenty & 1 & & & \\
\hline 6 & Tablica z modlitwami & 1 & & & \\
\hline \multicolumn{6}{|c|}{ A. Utensilia metalowe } \\
\hline 1 & $\begin{array}{l}\text { Monstrancja pozłacana z figurami św. Piotra i } \\
\text { Pawła, } 2 \text { aniołków }\end{array}$ & 1 & 535 & 00 & dar p. Delraux \\
\hline 2 & Kielich metalowy biały z pozłacaną pateną & 1 & 160 & 00 & $\begin{array}{l}\text { dar p. Bara- } \\
\text { nowskiego Z. }\end{array}$ \\
\hline 3 & Kielich metalowy biały z białą metalową pateną & 1 & 65 & 00 & \\
\hline 4 & Kielich metalowy biały stary & 1 & & & $\begin{array}{l}\text { niezdatny do } \\
\text { użytku }\end{array}$ \\
\hline 5 & Puszka metalowa biała & 1 & 140 & 00 & od p. Viliot M. \\
\hline 6 & Patena pozłacana do udzielania Komunii św. & 1 & & & \\
\hline 7 & Patena od infirmis pozłacana & 1 & 60 & 00 & \\
\hline 8 & $\begin{array}{l}\text { Naczynka od Olea św. metalowe z tacką meta- } \\
\text { lową białą }\end{array}$ & 3 & & & \\
\hline 9 & Naczynko metalowe kute & 1 & & & \\
\hline 10 & Lichtarze metalowe kute & 6 & & & $\begin{array}{c}\text { dar warsztatów } \\
\text { M. }\end{array}$ \\
\hline 11 & Lichtarze metalowe białe & 4 & 320 & 00 & $\begin{array}{l}\text { staraniem pana } \\
\text { Z. Baranow- } \\
\text { skiego }\end{array}$ \\
\hline
\end{tabular}




\begin{tabular}{|c|c|c|c|c|c|}
\hline 12 & Lichtarze brązowe, gotyckie & 1 & 24 & 00 & $\begin{array}{l}\text { dar pani Ko- } \\
\text { walskiej }\end{array}$ \\
\hline 13 & Lichtarzyki białe metalowe & 4 & & & \\
\hline 14 & Trybularz metalowy, biały & 1 & & & \\
\hline 15 & Łódka brązowa z łyżeczką & 1 & & & \\
\hline 16 & Lawaterz metalowy, biały & 1 & 46 & 00 & $\begin{array}{l}\text { staraniem pana } \\
\text { Z. Baranow- } \\
\text { skiego }\end{array}$ \\
\hline 17 & Kropielniczka metalowa, biała & 1 & 42 & 00 & $\begin{array}{l}\text { staraniem pana } \\
\text { Z. Baranow- } \\
\text { skiego }\end{array}$ \\
\hline 18 & Kociołek metalowy, biały & 1 & 115 & 00 & $\begin{array}{l}\text { staraniem pana } \\
\text { Z. Baranow- } \\
\text { skiego }\end{array}$ \\
\hline 19 & Kropidło metalowe & 1 & 20 & 00 & \\
\hline 20 & Dzwonki harmonijne & 2 & 100 & 00 & \\
\hline 21 & Dzwonki pojedyncze & 2 & & & \\
\hline 22 & Dzwonek przy zakrystii & 1 & & & \\
\hline 23 & Tacka mosiężna pod ampułki & 1 & & & \\
\hline 24 & Krzyżyk metalowy, biały & 1 & & & \\
\hline 25 & Dzbanek metalowy, do chrztu & 1 & 300 & 00 & $\begin{array}{l}\text { dar pana } \\
\text { Jana Hoppe }\end{array}$ \\
\hline 26 & Miedniczka metalowa do chrztu & 1 & & & \\
\hline 27 & Kandelabry metalowe potrójne & 2 & 236 & 00 & $\begin{array}{l}\text { staraniem pana } \\
\text { Z. Baranow- } \\
\text { skiego }\end{array}$ \\
\hline 28 & Lampa wieczna metalowa & 1 & 307 & 00 & $\begin{array}{l}\text { dar pana } \\
\text { Delbeck }\end{array}$ \\
\hline 29 & $\begin{array}{l}\text { Latarnie procesjonalne metalowe na drążkach } \\
\text { drewnianych }\end{array}$ & 4 & 500 & 00 & \\
\hline 30 & Latarnia metalowa od infirmos & 1 & 57 & 00 & \\
\hline 31 & Zacheuszkia metalowe & 12 & & & \\
\hline
\end{tabular}

${ }^{a}$ Zacheuszki - krzyże apostolskie, świeczniki apostolskie, zwyczajowo dwanaście. Umieszczone są w kościele w tych miejscach, które biskup namaścił podczas konsekracji kościoła. Występują w formie klocka, płytki z symbolicznym krzyżykiem. Są malowane lub ryte w ścianie. Pod nimi umieszcza się jednoramienny świecznik lub lampkę. W rycie rzymskim podczas dedykacji (poświęcenia) kościoła zapalano 12 świec zwanych zacheuszkami. Po Soborze Watykańskim zredukowano liczbę namaszczenia ścian kościoła do czterech. Nie zakazano jednak namaszczenia w 12 miejscach. Nazwa polska pochodzi od biblijnego imienia Zacheusz, który przyjął Jezusa w swoim domu. Świeczniki zapala się w rocznicę dedykacji kościoła. B. Nadolski, Leksykon liturgii, Poznań 2006, s. 1339. 


\begin{tabular}{|c|c|c|c|c|c|}
\hline \multicolumn{6}{|c|}{ B. Aparaty } \\
\hline 1 & $\begin{array}{l}\text { Ornat biały, wyszywany złotem, ozdobiony w } \\
\text { kwiaty i złotym galonem ze stułą, welonem i } \\
\text { bursą }\end{array}$ & 1 & & & \\
\hline 2 & $\begin{array}{l}\text { Ornat biały, prosty bez ozdób ze stułą, welonem } \\
\text { i bursą }\end{array}$ & 1 & 500 & 00 & $\begin{array}{l}\text { dar nauczyciel- } \\
\text { stwa }\end{array}$ \\
\hline 3 & $\begin{array}{l}\text { Ornat biały, ozdobiony różami ze stułą, welonem } \\
\text { i bursą w kolorze kremowym }\end{array}$ & 1 & & & $\begin{array}{l}\text { dar pani } \\
\text { Zuzanny } \\
\text { Fischerowej } \\
\text { z Krukowa }\end{array}$ \\
\hline 4 & $\begin{array}{l}\text { Ornat biały, stary, prosty ze stułą, welonikiem i } \\
\text { bursą }\end{array}$ & 1 & & & \\
\hline 5 & Ornat czerwony, prosty ze stułą, welonem i bursą & 1 & 70 & 00 & $\begin{array}{l}\text { staraniem pani } \\
\text { Lewickiej }\end{array}$ \\
\hline 6 & Ornat czerwony, stary & 1 & & & \\
\hline 7 & $\begin{array}{l}\text { Ornat zielony, nowy, ozdobiony, ze stułą, welo- } \\
\text { nem, bursą i man[ipularzem] }\end{array}$ & 1 & & & \\
\hline 8 & Ornat zielony, stary & 1 & & & \\
\hline 9 & $\begin{array}{l}\text { Ornat fioletowy, ozdobny z wyszytym mon[o- } \\
\text { gramem] JHS złotem, ze stułą, welonem i bursą }\end{array}$ & 1 & & & \\
\hline 10 & Ornat granatowo-jasny, stary & 1 & & & \\
\hline 11 & $\begin{array}{l}\text { Ornat czarny, aksamitny, ze stułą, welonem, bur- } \\
\text { są i mani[pularzem] }\end{array}$ & 1 & & & \\
\hline 12 & Ornat czarny, prosty stary & 1 & & & \\
\hline 13 & $\begin{array}{l}\text { Kapa biała, ozdobna w kwiaty z monagramem } \\
\text { złotym JHS ze stułą }\end{array}$ & 1 & & & \\
\hline 14 & Kapa biała, prosta stara & 1 & & & \\
\hline 15 & Kapa czerwona, prosta ze stułą & 1 & & & \\
\hline 16 & $\begin{array}{l}\text { Kapa filetowa, prosta ze stułą i monogramem } \\
\text { JHS ze złota }\end{array}$ & 1 & & & \\
\hline 17 & $\begin{array}{l}\text { Kapa czarna, prosta ze stułą z monogramem } \\
\text { jedwabnym JHS }\end{array}$ & 1 & & & \\
\hline 18 & $\begin{array}{l}\text { Stuła ozdobna, biała wyszywana w czerwone } \\
\text { róże }\end{array}$ & 1 & 65 & 00 & $\begin{array}{l}\text { staraniem } \\
\text { p. Lewickiej }\end{array}$ \\
\hline 19 & Stuła dwustronna, stara & 1 & & & \\
\hline 20 & Bursa do chorych, prosta & 1 & 50 & 00 & $\begin{array}{l}\text { staraniem } \\
\text { p. Lewickiej }\end{array}$ \\
\hline 21 & Welon biały, wyszywany w winogrona fioletowe & 1 & & & \\
\hline 22 & Sukienka do puszki, wyszywana w kwiaty & 1 & & & \\
\hline 24 & Sukienka do puszki, stara & 1 & & & \\
\hline
\end{tabular}




\begin{tabular}{|c|c|c|c|c|c|}
\hline \multicolumn{6}{|c|}{ C. Bielizna } \\
\hline 1 & Alby płócienne z koronką samodziałową & 1 & & & \\
\hline 2 & Alby z nansuku z koronką fabryczną & 3 & & & \\
\hline 3 & Humerały & 9 & & & \\
\hline 4 & Korporały & 10 & & & \\
\hline 5 & Palki & 7 & & & \\
\hline 6 & Puryfikaterze & 32 & & & \\
\hline 7 & Ręczniki do chrztu & 3 & & & \\
\hline 8 & Obrusy na ołtarze, płócienne ,ozdobne & 4 & & & \\
\hline 9 & Obrusy na ołtarze, płócienne, proste & 6 & & & \\
\hline 10 & Obrusy na stół do zakrystii & 2 & & & \\
\hline 11 & Komże duże & 9 & & & \\
\hline 12 & Komże małe & 15 & & & \\
\hline 13 & Paski & 7 & & & \\
\hline 14 & Ręczniki do lewaterzab $^{\mathrm{b}}$ & 12 & & & \\
\hline 15 & Zasłony płócienne do kratek & 2 & & & \\
\hline \multicolumn{6}{|c|}{ D. $\quad$ Przedmioty $z$ drzewa $i$ inne } \\
\hline 1 & Krzyże z metalową figurką na ołtarze & 2 & & & \\
\hline 2 & $\begin{array}{l}\text { Krzyż procesjonalny dębowy, z metalową figur- } \\
\text { ką }\end{array}$ & 1 & & & \\
\hline 3 & Krzyż procesjonalny czarny z metalową figurką & 1 & & & \\
\hline 4 & $\begin{array}{l}\text { Krucyfiks czarny, dębowy, z metalową figurką } \\
\text { do katafalku }\end{array}$ & 1 & & & \\
\hline 5 & Lichtarze dębowe, czarne & 4 & & & \\
\hline 6 & Fotel koszykowy z czerwonym obiciem & 1 & 45 & 00 & $\begin{array}{l}\text { staraniem pani } \\
\text { Lewickiej }\end{array}$ \\
\hline 7 & $\begin{array}{l}\text { Klęcznik dębowy, jasny z kratką, do słuchania } \\
\text { spowiedzi }\end{array}$ & 1 & 70 & 00 & \\
\hline 8 & Wieszak dębowy & 1 & & & \\
\hline 9 & Taboret metalowy, biały & 1 & & & \\
\hline 10 & Pulpit do mszału, drewniany & 1 & & & \\
\hline 11 & $\begin{array}{l}\text { Katafalk }{ }^{\mathrm{c}} \text { sosnowy o } 3 \text { kondygnacjach } \\
\mathrm{z} \text { trumienką }\end{array}$ & 1 & & & \\
\hline 12 & Flakony na kwiaty, ze szkła & 14 & & & \\
\hline
\end{tabular}

${ }^{\mathrm{b}}$ Lawaterz - naczynie metalowe (brąz, miedź) z wodą służące do polewania (obmycia) rąk przy obrzędach liturgicznych.

${ }^{\mathrm{c}}$ Katafalk - podwyższenie, na którym w kościele lub kaplicy pogrzebowej stawia się trumnę w czasie mszy pogrzebowej i obrzędu ostatniego pożegnania. Obecnie nie używany w liturgii. 


\begin{tabular}{|c|c|c|c|c|c|}
\hline 13 & $\begin{array}{l}\text { Obrazy drogi krzyżowej, oleodruki, ramy dębo- } \\
\text { we }\end{array}$ & 14 & & & \\
\hline 14 & $\begin{array}{l}\text { Poduszka procesjonalna, czerwono-biała } \mathrm{w} \\
\text { kwiaty z sercem P. Jezusa }\end{array}$ & 1 & \multirow{2}{*}{30} & \multirow{2}{*}{00} & \multirow{2}{*}{$\begin{array}{l}\text { staraniem pani } \\
\text { Lewickiej }\end{array}$} \\
\hline 15 & $\begin{array}{l}\text { Poduszka procesjonalna, czerwono-błękitna } \\
\text { zwykła }\end{array}$ & 1 & & & \\
\hline 16 & $\begin{array}{l}\text { Chorągiew biała Wniebowzięcia N.M.P. (ole- } \\
\text { odruk) }\end{array}$ & 1 & 140 & 00 & \\
\hline 17 & $\begin{array}{llll}\text { Chorągiew } & \text { czerwona } & \text { M[atki] } & \mathrm{B}[\text { ożej] } \\
\text { Różańcowej } & & & \\
\end{array}$ & 1 & & & \\
\hline 18 & $\begin{array}{l}\text { Chorągiew czarna z obrazem „Ecce Homo” wy- } \\
\text { szytym }\end{array}$ & 1 & & & \\
\hline 19 & $\begin{array}{l}\text { Baldachim z brokatu ze złotymi frędzlami, } \\
\text { ozdobny }\end{array}$ & 1 & 800 & 00 & $\begin{array}{l}\text { dar ks. [Pawła] } \\
\text { Stepka }\end{array}$ \\
\hline 20 & Kanony w ramach (druki) & 2 & & & \\
\hline 21 & $\begin{array}{l}\text { Umbraculum białe, ozdobione w kwiaty z wy- } \\
\text { szytym kielichem na dębowej nóżce }\end{array}$ & 1 & & & \\
\hline 22 & Sztandarek św. Kazimierza, czerwono-biały & 1 & 100 & 00 & $\begin{array}{l}\text { staraniem pani } \\
\text { Lewickiej }\end{array}$ \\
\hline 23 & Sztandarek św. Stanisława, czerwono-biały & 1 & 100 & 00 & $\begin{array}{l}\text { staraniem pani } \\
\text { Lewickiej }\end{array}$ \\
\hline 24 & Poduszka czerwona pod mszał & 1 & \multirow{2}{*}{25} & \multirow{2}{*}{00} & \\
\hline 25 & Poduszka czarna pod mszał & 2 & & & \\
\hline 26 & Pokrowiec czerwony na ołtarz & 1 & & & \\
\hline 27 & Pokrowiec w kratki & 1 & & & \\
\hline 28 & Pokrowiec czerwony & 1 & & & \\
\hline 29 & Pelerynki czerwone dla ministrantów & 4 & & & \\
\hline 30 & $\begin{array}{l}\text { Figura } \mathrm{P}[\text { ana] Jezusa Zamartwychwstałego } \mathrm{z} \\
\text { masy }\end{array}$ & 1 & & & \\
\hline 31 & Dywan duży, stary na stopnie & 1 & & & \\
\hline 32 & Dywaniki małe, stare & 2 & & & \\
\hline 33 & Szopka o 24 figurkach z masy & 1 & 177 & 00 & dar p. Hórle \\
\hline 34 & Taca wyplatana & 1 & & & \\
\hline 35 & $\begin{array}{l}\text { Obraz w „Ecce Homo” oleodruk w ciemnej bo- } \\
\text { gatej remie }\end{array}$ & 1 & & & \\
\hline 36 & $\begin{array}{l}\text { Obraz Serca P[ana] Jezusa, oleodruk w ciemnej } \\
\text { bogatej ramie }\end{array}$ & 1 & & & \\
\hline 37 & $\begin{array}{l}\text { Obraz M[atki] B[oskiej] Częstochowskiej, ole- } \\
\text { odruk }\end{array}$ & 1 & 15 & 00 & \\
\hline
\end{tabular}




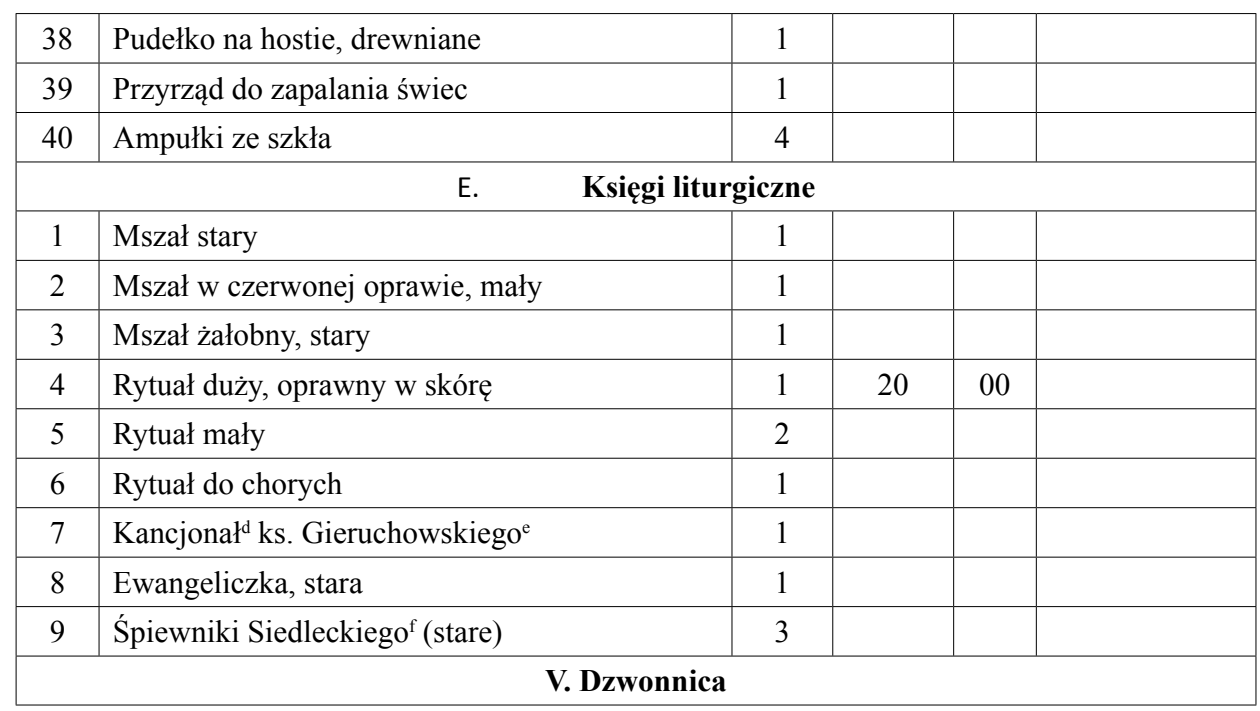

${ }^{\mathrm{d}}$ Kancjonał (łac. cantus śpiew) - zbiór popularnych kościelnych pieśni religijnych lub śpiewów liturgicznych używanych od XIV wieku w liturgii przez katolików i protestantów. Nazwa z czasem została zastąpiona przez bardzie spopularyzowaną: ,kantyczki”.

e Prawdopodobnie chodzi o jezuitę Gelarowskiego (Gielarowski) Bonawenturę (1657-1711). Urodził się w Wielkopolsce, wstąpił do jezuitów w 1674 rok w Krakowie. Był profesorem retoryki w Grudziądzu, Kaliszu, Lwowie oraz misjonarzem w Kowlu. Przez krótki czas był prefektem szkół we Lwowie. Jest autorem wznawianych dwukrotnie kazań: Kazania na niedziele całego roku i Święta Chrystusowe od X. Bonawentury Gelarowskiego Soc. Jesu miane, Torun 1727, Sandomierz 1738. Gelarowski Bonawentura, w: Encyklopedia wiedzy o jezuitach na ziemiach Polski $i$ Litwy 1564-1995, opr. L. Grzebień, Kraków 1996, s. 177.

${ }^{\mathrm{f}}$ Ks. Jan Siedlecki (1829-1902) - wydawca, autor najstarszego Śpiewnika Kościelnego, ukazującego się od 1878 roku (w Krakowie) do dziś. Urodził się w Warszawie. Tam wstąpił w 1847 roku do Zgromadzenia Księży Misjonarzy św. Wincentego a Paulo. Teologię studiował seminarium duchownym przy kościele Świętego Krzyża w Warszawie. Tam przyjął święcenia kapłańskie w 1852 roku. Pracował w seminarium i w duszpasterstwie parafialnym. Był kapelanem i spowiednikiem sióstr szarytek we Lwowie 1861-1863, kapelanem sióstr szarytek w Krakowie, od 1864 roku administratorem domu zakonnego w Krakowie. Gromadząc środki na wykończenie fasady kościoła seminaryjnego, podjął się ryzykownych operacji giełdowych, które przyniosły straty finansowe zgromadzeniu. $Z$ tego powodu opuścił zgromadzenie i został przyjęty do diecezji krakowskiej. W latach 1874-1884 był katechetą w szkole przy kościele św. Barbary w Krakowie, w latach 1878-1895 spowiednikiem w Kościele Mariackim, 1889-1895 rektorem kościoła św. Wojciecha. Od 1896 roku mieszkał w domu księży emerytów przy kościele św. Marka w Krakowie. Najważniejszym jego dziełem jest „Śpiewniczek pieśni kościelnych dla użytku młodzieży szkolnej” (Kraków 1876). Do kolejnych jego wydań (Kraków 1878) dołączył nuty, dzięki czemu śpiewnik zyskał popularność w Galicji i Królestwie Polskim. Od 1928 roku wydawany był jako „Śpiewnik kościelny”. W. Umiński, Siedlecki Jan, EK, t. 18, Lublin 2013, kol. 136. 
Dzwonnica drewniana prowizoryczna

Dzwon wagi 60 kg ofiarowali inżynierowie: Piotr Czerniewski, Stanisław Jarek, Albert Gilard, Bolesław Rejman. Odlany w stoczni Gdańskiej w 1936 roku. Napis na dzwonie: „Święty Józefie wspieraj nas w pracy"

\section{Cmentarz kościelny}

Obszar cmentarza 49 metrów długości, szerokości 35 mtr[=metrów].

Ogrodzenie od ulicy ze sztachetów (sic) z bramą drewnianą i 2 furtkami.

\section{Cmentarz grzebalny}

$1 \quad$ Cmentarz grzebalny katolicki poza wsią Rudnia.

Ogrodzenie drewniane w stanie dobrym.

Bramy wejściowe drewniane. Obszar cmentarza wynosi około $5000 \mathrm{~m}^{2}$. Specjalnego dozoru nie ma.

2 Cmentarz grzebalny w Morszczynowiczach. Ogrodzenie drewniane. Obszar $1209 \mathrm{mtr}^{2}$. Wspólny z prawosławnymi.

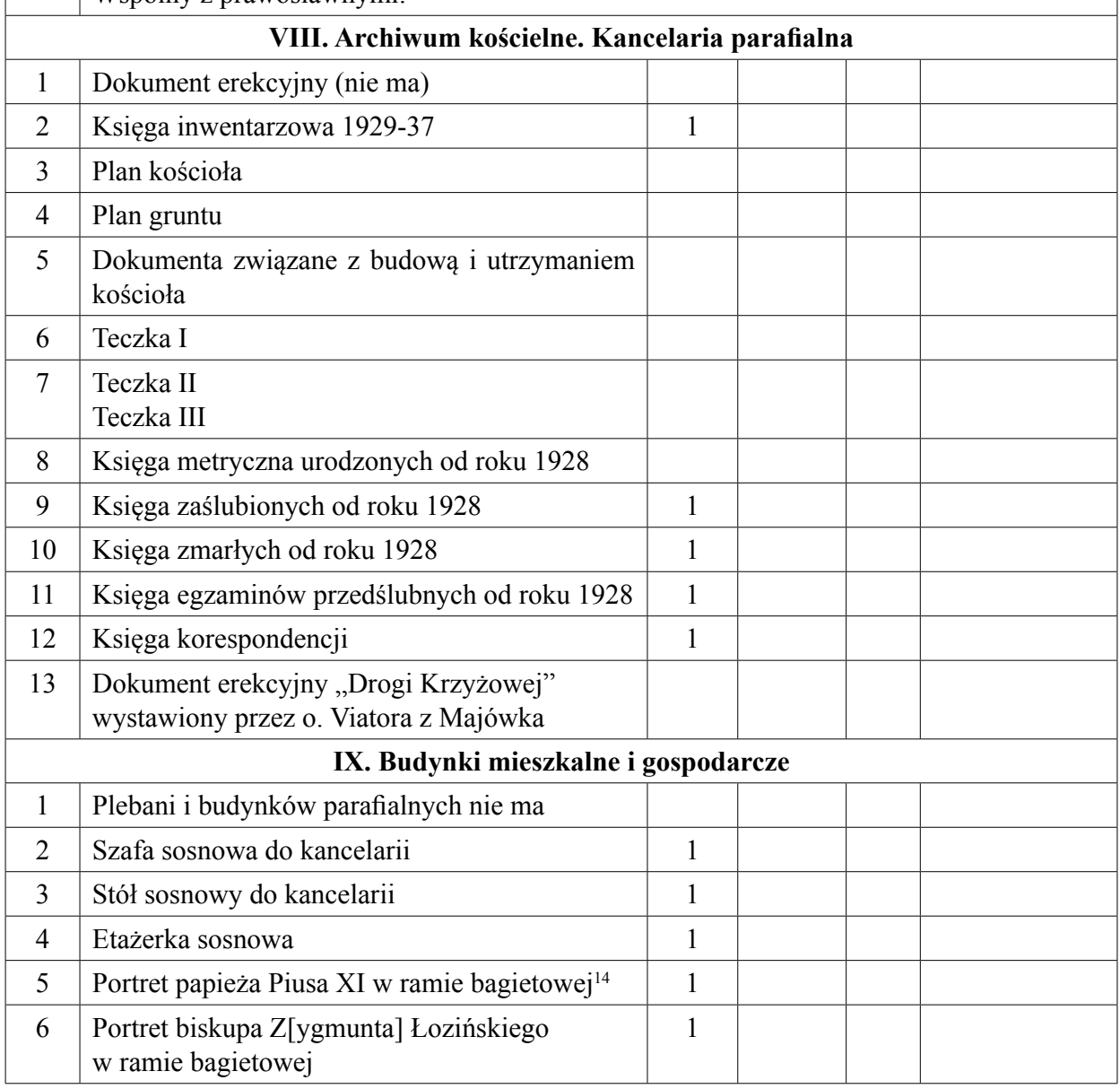

${ }^{\mathrm{g}}$ Bagieta - ozdobna listwa drewniana używana do wyrobu ram, gzymsów i do dekoracji wnętrz 


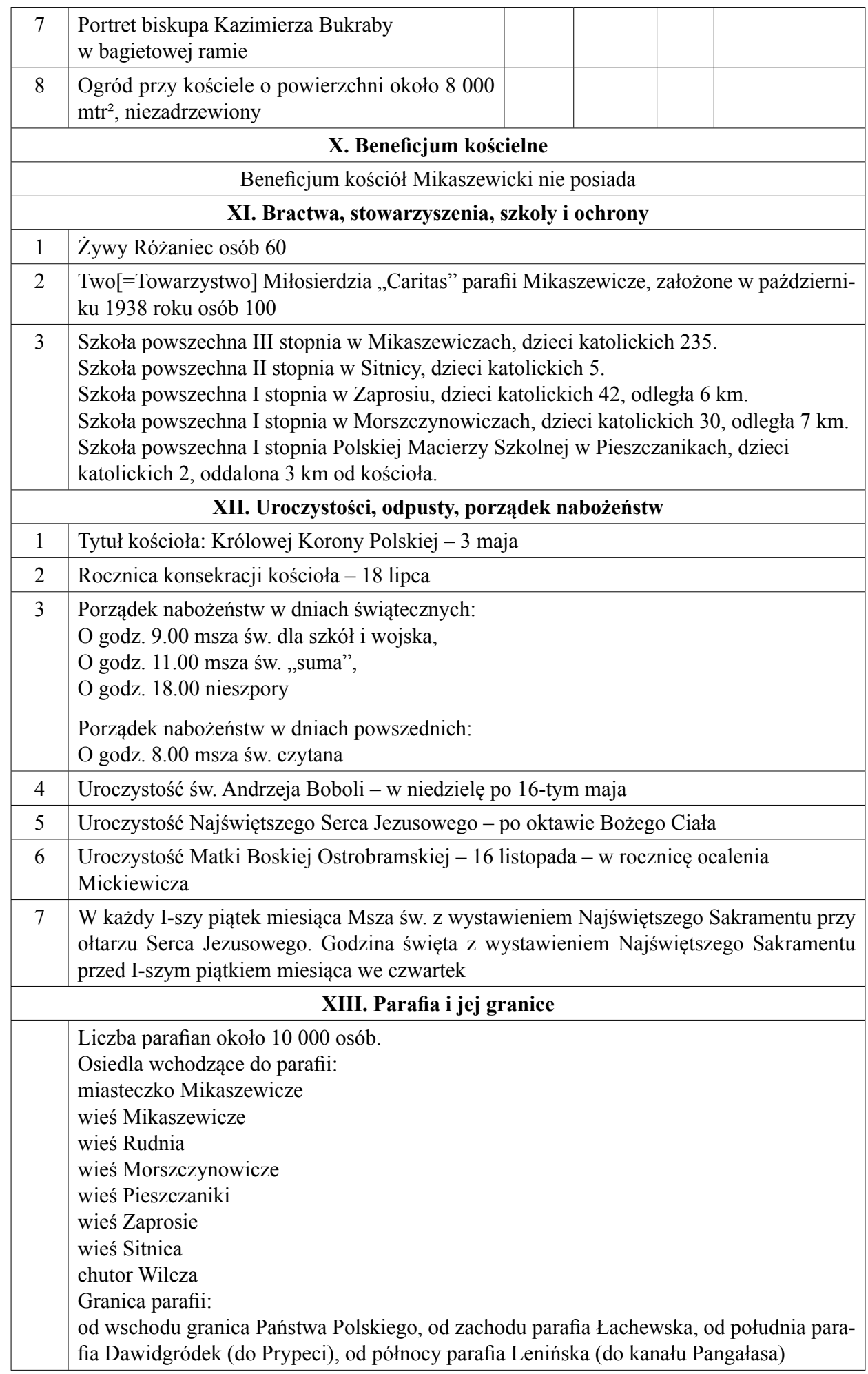




\section{KRONIKA PARAFII}

Mikaszewicze i okoliczne wioski należały najdawniej do parafii w Dawidgródku, skąd dojeżdżali od czasu do czasu kapłani. Mniej więcej od 1921 roku Mikaszewicze należały do parafii Łachwa. Z Łachwy kapłani dojeżdżali mniej więcej raz na miesiąc, a w razie potrzeby to i częściej. W roku 1927 następuje erekcja parafii na miejscu przez ks. biskupa ordynariusza Zygmunta Łozińskiego. Dokładnego dokumentu w tym względzie nie ma. Pierwszym proboszczem zostaje ksiądz Paweł Stepek, urodzony $<\mathrm{w}>1877$ roku, wyświęcony na kapłana w 1912 roku. Szczegóły o nim podane są we wstępie niniejszej księgi. Rządzi parafią do roku 1934-go, miesiąca września. Stąd odjeżdża do Hajnówki.

Ksiądz Wincenty Siudziński rządził parafia od 1 IX 1934 roku do 15 VII 1935 roku. Za jego czasu założono fundamenty kościoła.

Ksiądz Bronisław Wieliczko, urodzony <w> 1903 roku, wyświęcony na kapłana w 1933 roku, rządzi parafią od roku 1935-go, miesiąca lipca do roku 1938, miesiąca września. Dnia 18 października 1936 roku, ks. dziekan łuniniecki, Mieczysław Pietrykowski ${ }^{11}$ poświęca nowobudowany kościół. Dnia 18 lipca 1937 roku - konsekracja kościoła i dzwonu przez księdza biskupa Kazimierza Bukrabę.

Ksiądz Jan Karnicki, urodzony <w> 1908 r., wyświęcony na kapłana <w> 1935 r., rządzi parafią od września 1938 do kwietnia 1939. Przy nim bardzo rozwija się Towarzystwo Dobroczynności „Caritas”. Od dnia 28 IX - 8 X 1938 roku odbywają się misje parafialne, prowadzone przez ojców kapucynów. W kwietniu 1939 roku zostaje zabrany do Wojska Polskiego na kapelana i odtąd już nie wraca do parafii.

Ks. Kazimierz Dąbrowski (lipiec), ks. Józef Zając (sierpień, wrzesień do 17go). Po oddaleniu się ostatniego parafia była bez pasterza do 10 października $<1939$ roku>.

Ks. Urban Filipek, urodzony dn. 5 IX 1909 roku, wyświęcony na kapłana dn. 31 III 1934 roku, przybywa do Mikaszewicz z Lenina dnia 10 X 1939 roku naznaczony na administratora przez ks. dziekana łuninieckiego, Fabjana Poczobutt-Odlanickiego. Rządzi parafią przez lata okupacji bolszewickiej (1939, 1940, 1941) i niemieckiej 1941, 1942, 1943, 1944...

Dnia 30 czerwca 1940 roku poświęca parafię Najśw[iętszemu] Sercu Jezusowemu. Dnia 20 XII 1942 roku poświęca ołtarz Najśw[iętszego] Serca Jezusowego. Dnia 6 VI 1943 poświęca ołtarz św. Andrzeja Boboli.

Bardzo ciężkie chwile przeżywała parafia lata okupacji bolszewickiej i niemieckiej. Szczególnie tragiczną chwilę przeżyły Mikaszewicze i okolica od 16-go do 19-go listopada 1942 roku. Wszyscy mieszkańcy mieli zginąć od Niemców za 50 ofiar niemieckich, które zginęły z rąk partyzantów w sali kina. Bóg Miłosierny odwrócił tę klęskę. Szczególnie przyczynił się do tego Ortskomendant niemiecki p. Szmela. On bardzo bronił miejscową ludność. Po ocaleniu nastąpiło

${ }^{11}$ Ks. Pietrzykowski Mieczysław (ur. 1878) - kapłan diecezji pińskiej. Wyświęcony w 1902 roku. Od 1933 roku był proboszczem parafii św. Józefa w Łunińcu i dziekanem łuninieckim. Poświęcił w 1936 roku wybudowany kościół w Mikaszewiczach. Spis kościołów i duchowieństwa diecezji pińskiej w R. P. 1937, Pińsk 1937, s. s. 25, 107, 176. 
w Mikaszewiczach i w parafii odrodzenie duchowe. Ludność bardzo modliła się i dziękowała Bogu. Liczne były przystępowania do sakramentów św. Liczne były nawrócenia.

Dnia 6 lipca 1944 roku z powodu zbliżania się frontu ludność była ewakuowana. W miasteczku zostali tylko ci, którzy się skryli. Pierwszy transport robotniczy odszedł w liczbie około 700 osób do Bydgoszczy. Drugi transport kolejowy w liczbie około 300 osób odszedł bez celu, byleby dalej od frontu. Ks. Urban Filipiak wyjechał wraz z gospodynią, służącą, zakrystianinem transportem kolejowym. Wyładował się w Siedlcach. Ach, jaki to był żal, gdyśmy opuszczali Mikaszewicze, a szczególnie kościół tak nam drogi.

Ks. Urban Filipiak. Pisałem w Wiomie.

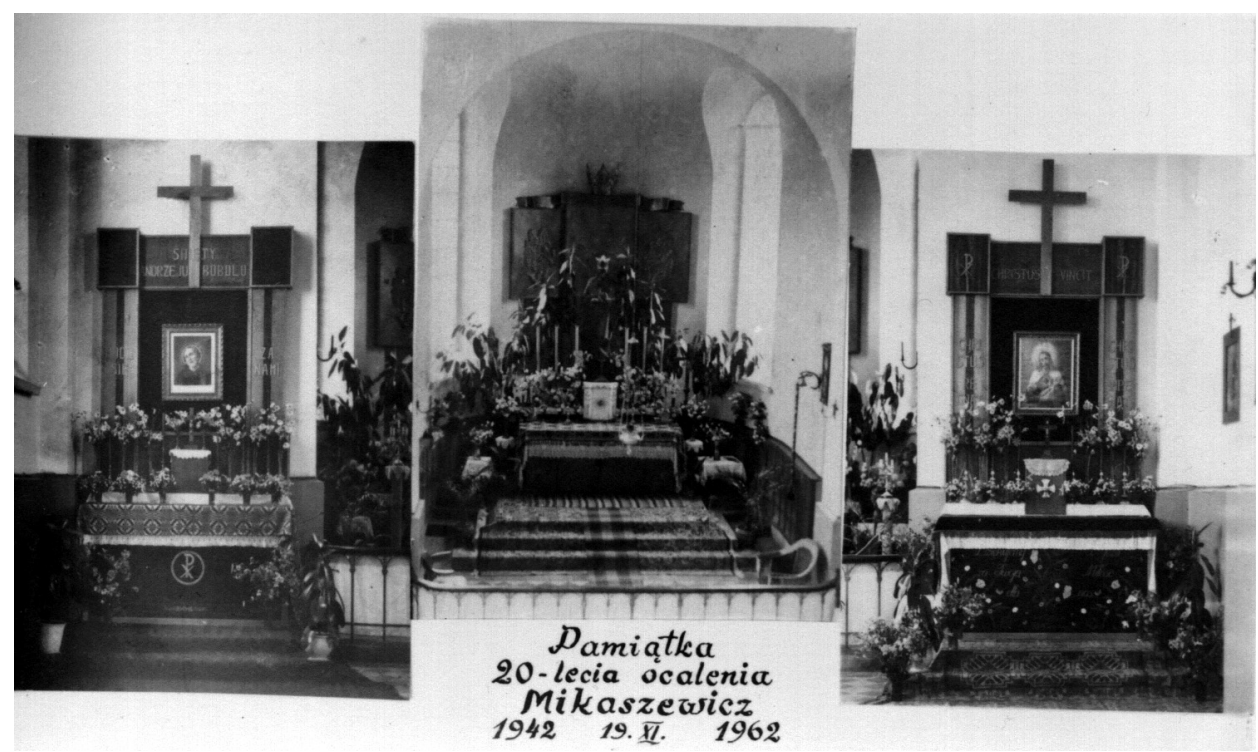

Fot. 5 20-lecie ocalenia kościoła parafialnego w Mikaszewiczach 1942-1962.

słowa kluczowe: polskie Kresy Wschodnie; historia Kościoła; parafia rzymskokatolicka w Mikaszewiczach w diecezji pińskiej 


\title{
BIBLIOGRAFIA
}

Niech świadectwo nie będzie zapomniane, opr. L. Michajlik, Grodno 2000.

Gelarowski Bonawentura, w: Encyklopedia wiedzy o jezuitach na ziemiach Polski i Litwy 1564-1995, opr. L. Grzebień, Kraków 1996, s. 177.

Jacewicz Wiktor, Martyrologium polskiego duchowieństwa rzymskokatolickiego pod okupacja hitlerowska w latach 1939-1945, Warszawa 1977.

Misiurek Jerzy, Łoziński Zygmunt, w: Encyklopedia Katolicka, t. 11, Lublin 2006, kol. 554-555.

Petrani Aleksy, Bukraba Kazimierz, w: Encyklopedia Katolicka, t. 2, Lublin 1985, kol. 1189-1190.

Nadolski Bogusław, Leksykon liturgii, Poznań 2006.

Spis kościołów i duchowieństwa diecezji pińskiej w R. P. 1935, Pińsk 1935.

Spis kościołów i duchowieństwa diecezji pińskiej w R. P. 1937, Pińsk 1937.

Stachowiak Jan Bogumił, Pro Ecclesia et Pontifice, w: Encyklopedia Katolicka, t. 16, Lublin 2012, kol. 409.

Umiński Wacław, Siedlecki Jan, w: Encyklopedia Katolicka, t. 18, Lublin 2013, kol. 136.

Urban Wincenty, Duszpasterska siejba kapłanów-repatriantów na ziemiach odzyskanych w latach 1945-1970, Wrocław 1972.

\section{Netografia}

https://pl.wikipedia.org/wiki/Jan_Karnicki (dostęp: 28.02.2017).

http://www.encyklopedia.puszcza-bialowieska.eu (dostęp: 28.02.2017).

\section{THE ROMAN CATHOLIC PARISH OF MIKASZEWICZE ACCORDING TO THE CHURCH INVENTORY OF 1938}

\begin{abstract}
Summary
Mikaszewicze in Polesie, Poland, developed quite intensely thanks to the construction of the railway, the factory of plywood and the sawmill. This town developed after Poland regained its independence in 1918. The factories which were built there attracted a number of workers, which led to the creation of a fairly large town with a workers' settlement in 1938. Then there was a need to erect a separate parish and, given that the neighbouring villages of Rudnia, Morszczynowicze and Zaprosie accepted the Orthodox faith in the period of Poland's captivity. Initially, the parish priests from Dawidgródek and Łachwa celebrated church services in private houses and later in the school in Mikaszewicze. In 1923, attempts were made to establish a new pastoral and parish centre. In 1927, the Ordinary of Pińsk erected a parish dedicated to the Queen of the Crown of Poland, and Rev. Pawel Stepak was appointed a parish priest. The church, built in a mixture of Gothic and Romanesque style, was consecrated on 18 July 1937 by Bishop Kazimierz Bukraba.
\end{abstract}

Keywords: the Polish Eastern Borderlands; the history of the Church; the Roman Catholic Parish of Mikaszewicze in the Diocese of Pińsk 


\section{РЫМСКА-КАТАЛЮЦКАЯ ПАРАФІЯ Ў МІКАШЭВІЧАХ, ПІНСКАЙ ДЫЯЦЭЗІІ Ў СВЯТЛЕ ІНВЕНТАРА КАСЦЁЛА 31938 Г.}

\section{СКАРАЧЭННЕ}

Польскае і палескае пасяленне Мікашэвічы развівалася даволі хутка дзякуючы будове побач з ім чыгункі, фанернай фабрыкі і тартаку. Пасля атрымання Польшчай непадлегласці ў 1918 г. гэтая мясцовасць развілася яшчэ шырэй. Новыя прадпрыемствы прыцягвалі да Мікашэвічаў працаўнікоў настолькі актыўна, што ў 1938 г. там паўстала вялікае мястэчка з рабочым пасёлкам. 3'явілася патрэба стварэння там новай асобнай парафіі разам з усім забеспячэннем, тым больш, што навакольныя вёскі Рудня, Маршчынавічы і Запроссе ў часах няволі сталі праваслаўнымі. Спачатку набажэнствы ў Мікашэвічах адпраўлялі час да часу пробашчы з Давыдгарадка і Лахвы - спачатку ў прыватным доме, а потым у школе. У 1927 г. Пінскі ардынарый эрыгаваў у Мікашэвічах парафію пад тытулам Каралевы Кароны Польскай, а на пасаду пробашча прызначыў кс. Паўла Стэпака. Святыня была пабудавана ў стылі гатыцкім, злучаным з раманскім. Кансэкрацыю касцёла ў Мікашэвічах здзейсніў 18 ліпеня 1937 г. біскуп Казімір Букраба.

Ключовыя словы: Польскія Усходнія Крэсы; гісторыя Касцёла; рымска-каталіцкая парафія ў Мікашэвічах; Пінскай дыяцэзіі

Перевод Лауры Михайлик

\section{РИМСКО-КАТОЛИЧЕСКИЙ ПРИХОД В МИКАШЕВИЧАХ, ПИНСКОЙ ЕПАРХИИ В СВЕТЕ ИНВЕНТЯРЯ ХРАМА С 1938 Г.}

\section{СОДЕРЖАНИЕ}

Польское и полесское поселение Микашевичи развивалось довольно быстро, благодаря строительству рядом с ним железной дороги, фанерной фабрики и лесопилки. После обретения Польшей независимости в 1918 г. эта местность развивалась еще интенсивней. Новые предприятия притягивали в Микашевичи работников настолько активно, что в 1938 г. там образовалось большое местечко с рабочим поселком. Появилась потребность создания там нового отдельного прихода вместе со всем необходимым, тем более, что соседние деревни: Рудня, Морщиновичи и Запросье в годы неволи стали православными. Сначала богослужения в Микашевичах время от времени вели настоятели из Давыдгородка и Лахвы, вначале в частном доме, а затем в школе. В 1927 г. Пинский ординарий создал в Микашевичах приход под титулом Корролевы Короны Польской, а на должность настоятеля назначил о. Павла Степака. Храм был построен в сочетании готического и романского стилей. Консекрацию костела совершил 18 июля 1937 г. Пинский епископ Казимир Букраба.

Ключевые слова: Польские Восточные Кресы; история Костёла; римско-католический приход в Микашевичах; Пинской епархии. 